\title{
VITAL PULP THERAPY USING PLATELET-RICH FIBRIN IN AN IMMATURE PERMANENT TOOTH : CASE REPORTS
}

\author{
Ka-Young Lee, Sang-Ho Lee, Nan-Young Lee \\ Department of Pediatric Dentistry, College of Dentistry, Chosun University
}

\section{Abstract}

Preserving the pulp is important in the treatment of carious pulp exposure in young permanent teeth. Pulpotomy is a vital pulp therapy in which a portion of the coronal pulp tissue is surgically removed, and the remaining radicular tissue is covered with suitable material that protects the pulp from further injury and permits and promotes healing. It is important to develop biocompatible treatment directed at maintaining pulp vitality and increasing tooth longevity. Platelet-rich fibrin (PRF) has been referred to as a second-generation platelet concentrate.

Two clinical cases in which PRF was applied as a medicament after pulpotomy of an immature permanent tooth are presented. After isolation, caries removal and pulpotomy with PRF was performed. A layer of mineral trioxide aggregate (MTA) was placed over the PRF, and the final restoration was performed. Postoperatively, the patient had no pain or discomfort, and follow-up radiographs revealed normal periodontal ligament space and trabecular bone pattern.

Key words : Pulpotomy, Platelet-rich fibrin, Immature permanent toot

\section{Introduction}

Preserving the pulp is important in the treatment of carious pulp exposure in young permanent teeth ${ }^{11}$. Apexogenesis has been used in vital pulp therapy in immature teeth. The chief purpose of caries-exposed dental pulps in immature teeth is to maintain pulp vitality and allow for the continuation of root development and apical closure ${ }^{2)}$.

Apex formation in young permanent teeth can be accomplished by the appropriate vital pulp therapy, such as indirect pulp treatment, direct pulp capping, and pulpotomy for carious exposure. Pulpotomy is a vital pulp therapy, and the remaining radicular tissue is cov- ered with a material that protects the pulp from further injury and permits and promotes healing ${ }^{3)}$.

Calcium hydroxide and mineral trioxide aggregate (MTA) are typical materials used for vital pulp therapy of immature permanent teeth. Calcium hydroxide has been the material of choice for vital pulp therapy for many decades ${ }^{4)}$. Despite its common use, calcium hydroxide has disadvantages, including tunnel defects in induced dentinal bridges, poor adherence to dentine, and lack of a long-term seal ${ }^{5}$. MTA provides a long-term seal and acceptable biocompatibility ${ }^{6}$. However, MTA in its freshly mixed state shows cytotoxicity ${ }^{7.8}$, which could be due to its high $\mathrm{pH}^{9)}$.

It is important to develop biocompatible treatment di-

Corresponding author: Sang-Ho Lee

Department of Pediatric Dentistry, College of Dentistry, Chosun University, 375 Seosuk-dong, Dong-gu, Gwangju, 501-825, Korea

Tel: +82-62-220-3860 / Fax: +82-62-220-8240 / E-mail: shclee@chosun.ac.kr

Received April 10, 2013 / Revised May 8, 2013 / Accepted May 8, 2013 
rected at maintaining pulp vitality and increasing tooth longevity ${ }^{10)}$. Vital pulp therapies establish a biologically acceptable environment for the pulp tissue and prevent future bacterial contamination by using appropriate materials ${ }^{11)}$. The materials should be biocompatible and bactericidal, provide a biologic seal, and induce hard tissue formation ${ }^{1.111}$. One such biologically based material is platelet-rich fibrin (PRF), which is obtained by removing the middle layer from a centrifuged blood sample. PRF was first described by Choukroun et al. ${ }^{12}$, and it has been referred to as a second-generation platelet concentrate. It has been shown to have several advantages over traditionally prepared platelet-rich plasma (PRP). Its chief advantages include ease of preparation and lack of biochemical handling of blood, which makes this preparation strictly autologous ${ }^{12}$. Two cases are presented in which PRF was used as pulpotomy material to treat carious pulp exposure in immature permanent teeth.

\section{Case Reports}

Two cases were studied in the Department of Pediatric Dentistry, Chosun University Dental Hospital. There were no specific findings in the family, medical, or dental history of the patient.

\section{Case 1}

A 9-year-old girl was referred with a chief complaint of dental caries in the left mandibular first molar. On clinical examination, severe caries on occlusal and buccal surface were observed. A periapical radiograph revealed deep caries invading the pulp with open apexes of the left mandibular first molar (Fig. 1A).

The patient was informed about the treatment modality of coronal pulpotomy using PRF as an alternative treatment to root canal treatment. After obtaining consent from the patients, PRF was prepared by collecting
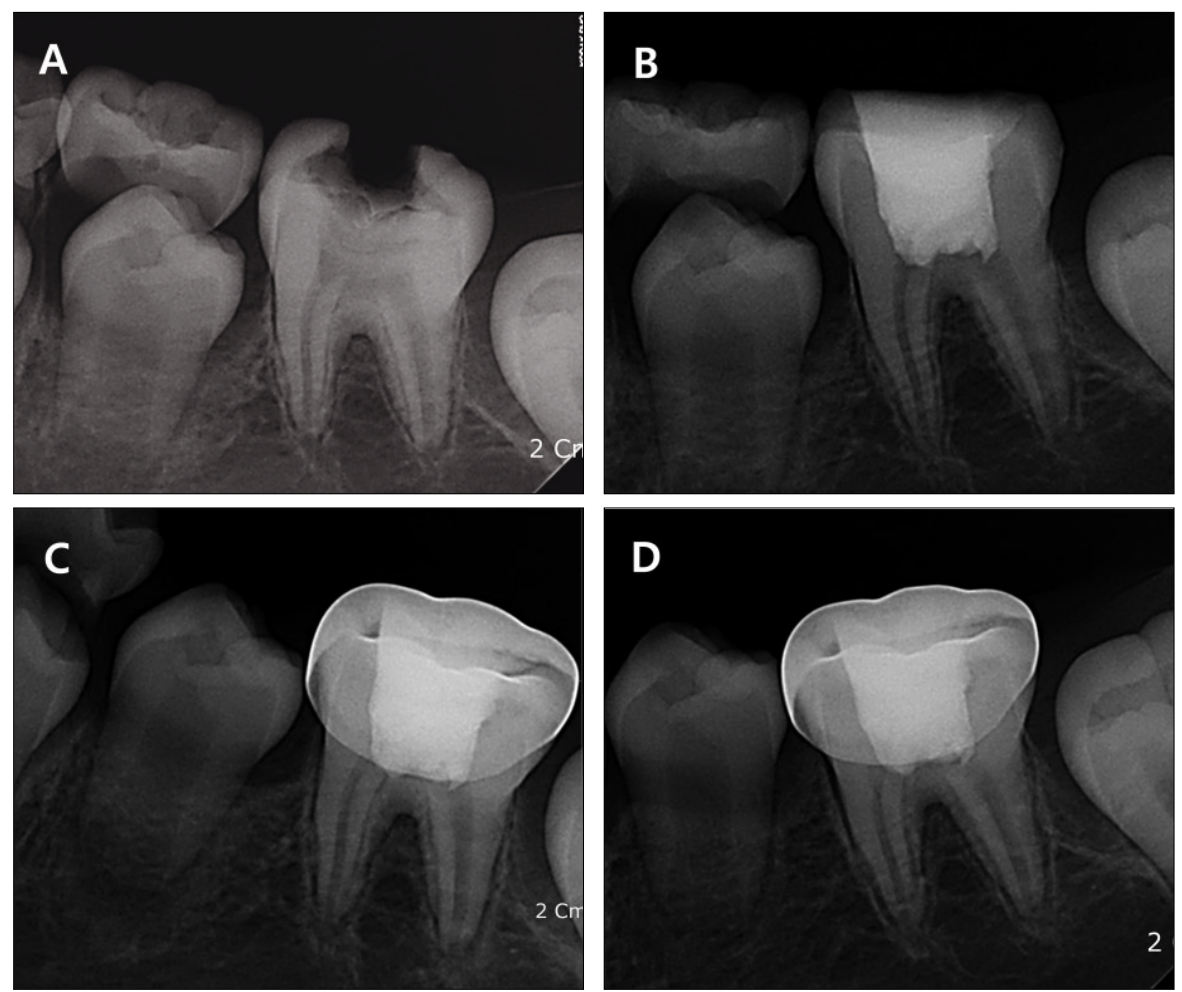

Fig. 1. Periapical view of the case 1 (A) Preoperative radiograph showing a deep caries of the left mandibular first molar. (B, C, D, E) Follow-up radiographs showing the periapical status at 1 month, 3 months, and 7 months, respectively. The images revealed normal periodontal ligament space, lamina dura, and trabecular pattern around the root apex. 
the required amount of blood into a $10 \mathrm{~mL}$ tube without anticoagulant and centrifuging it immediately using a centrifuge for $10 \mathrm{~min}$ at 3,000 rpm. The resultant product consisted of three layers (Fig. 2A). PRF was obtained in the form of a membrane by removing the fluids from the fibrin clot (Fig. 2B).

The tooth was first anesthetized and isolated with a rubber dam. Pulpotomy was performed with a round bur in a high-speed handpiece with copious irrigation; coronal pulp tissue was removed to the level of the pulp chamber floor (Fig. 3A). Hemostasis was achieved by irrigating the cavity with sterile saline and cotton pellets (Fig. 3B). The blood clot-free pulpal wound was covered with a small piece of PRF (Fig. 3C). An approximately 2 mm thick layer of MTA (ProRoot, Dentsply Tulsa Dental Specialty, Tulsa, OK, USA) was placed over the PRF (Fig. 3D). After 1 week, the patient revisited without any symptom, and glass-ionomer cement was placed over the MTA. The patient was followed-up after 1 month and crown was placed on left mandibular first molar. The patient had no pain or discomfort, and radiographic examination revealed normal periodontal liga- ment space and that the alveolar bone had normal trabecular pattern at 1 month and 3 months follow-up (Fig. 1B,C). After 7 months, lengthening and thickening of roots with normal periodontal ligament space were $\mathrm{ob}^{-}$ served(Fig. 1D).
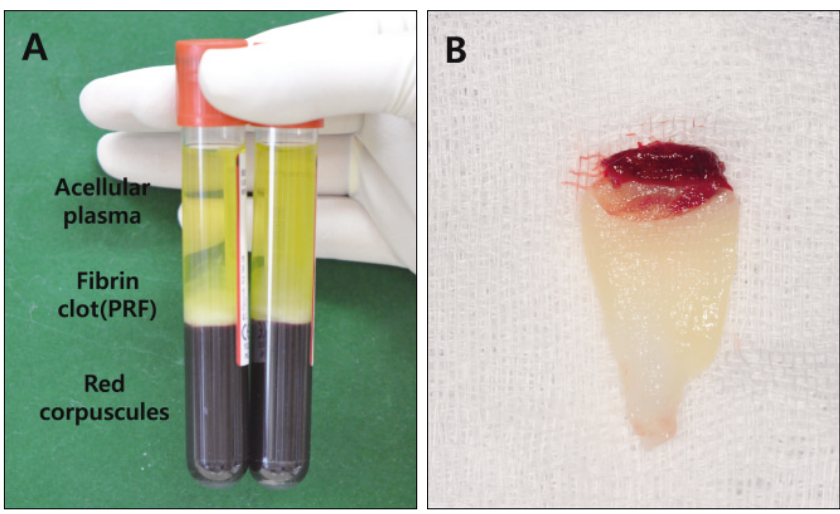

Fig. 2. (A) Characteristics of blood samples after centrifugation. A fibrin clot in the middle of the tube (PRF) between the red blood corpuscles at the bottom and acellular plasma at the top of the tube. (B) The membranelike material (PRF) achieved by removing the fluids.
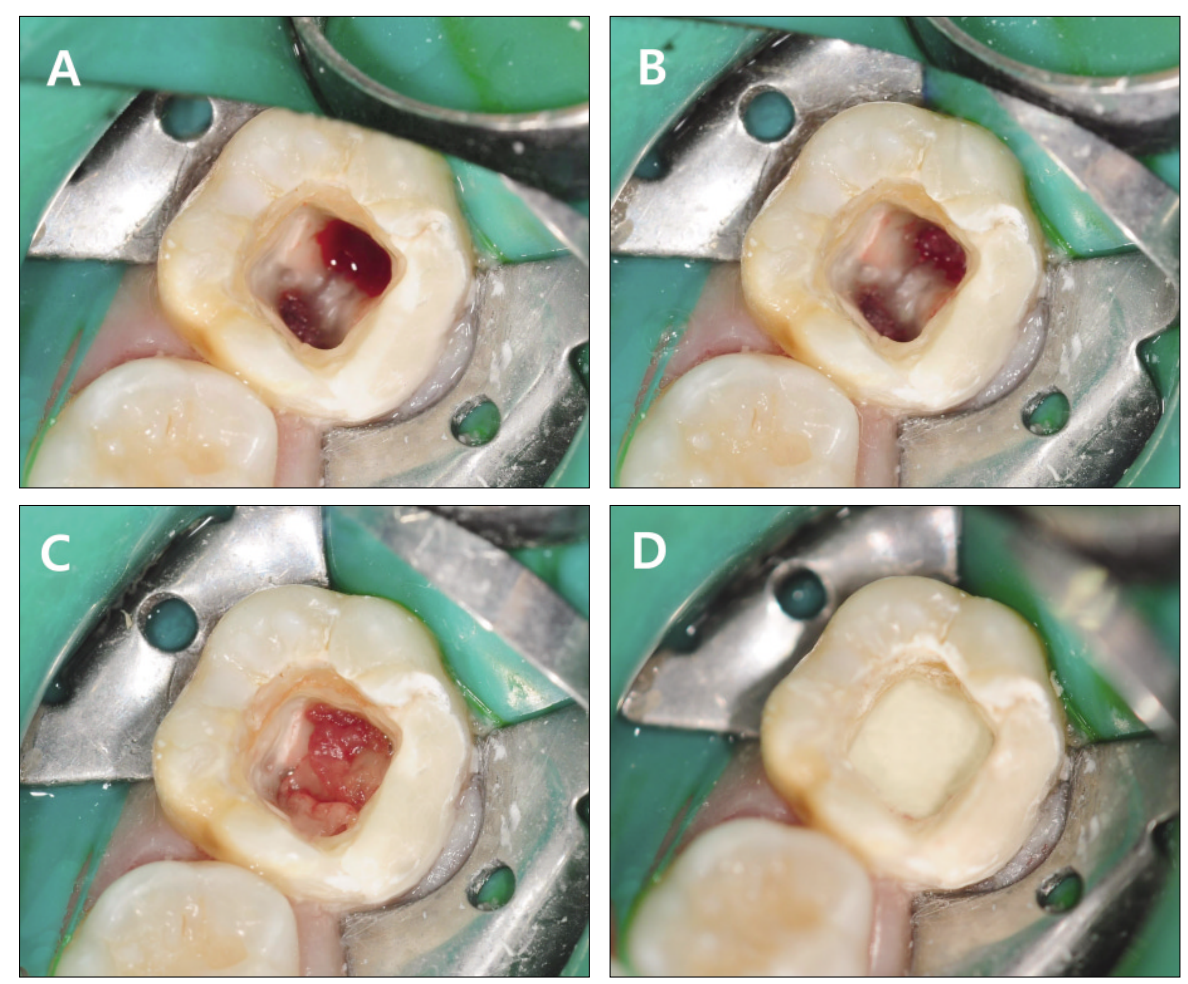

Fig. 3. Pulpotomy procedure performed with PRF. (A) Coronal pulp tissue was removed to the level of the pulp chamber floor. (B) Hemostasis was achieved by irrigating with sterile saline and drying with a cotton pellet. (C) PRF was placed over the radicular pulp tissue. (D) MTA was placed over the PRF. 


\section{Case 2}

A 12-year-old girl was referred from a local clinic due to caries control of the right mandibular second molar. On clinical examination, severe caries on the occlusal and lingual surface were observed. Periapical radiograph revealed deep caries invading the pulp and open apexes of the right mandibular second molar (Fig. 4A). The patient also complained of intermittent pain.

Pulpotomy with PRF was performed, and MTA was placed over the PRF. The patient was followed-up after 1 week for radiographic examination and postoperative pain evaluation. The patient had no pain or discomfort, and glass-ionomer cement was placed over the MTA.

After 1 month, a crown was placed on the right mandibular second molar. Radiographic examination revealed normal periodontal ligament space and that the alveolar bone had a normal trabecular pattern (Fig. 4B). After 3 months, 7 months, and 11 months, lengthening and thickening of roots and a normal trabecular pattern of the alveolar bone were observed (Fig. 4C,D,E).

\section{Discussion}

Dental caries and their sequela are the greatest challenge to the integrity of developing teeth. Carious pulp exposure in immature teeth causes irreversible damage to the pulp tissue and arrests root development, which can negatively influence the long-term prognosis of tooth retention ${ }^{11}$. Pulpotomy is a universally accepted treatment for teeth with incompletely formed roots involving carious pulp exposure ${ }^{1)}$.

The patient's age may play an important role in the success rate of vital pulp therapies and healing, as younger pulps are more cellular and have a greater blood supply ${ }^{13)}$. In this study, the patient was 9 and 12 years old. As immature permanent teeth do not respond to pulp tests reliably ${ }^{20)}$, a pulp test for diagnosis has not been conducted before treatment. The clinical selection criteria were patient's signs/symptom and clinical carious exposure.

Apexogenesis treatment has been contraindicated in cases of carious pulp exposure with symptomatic irre-
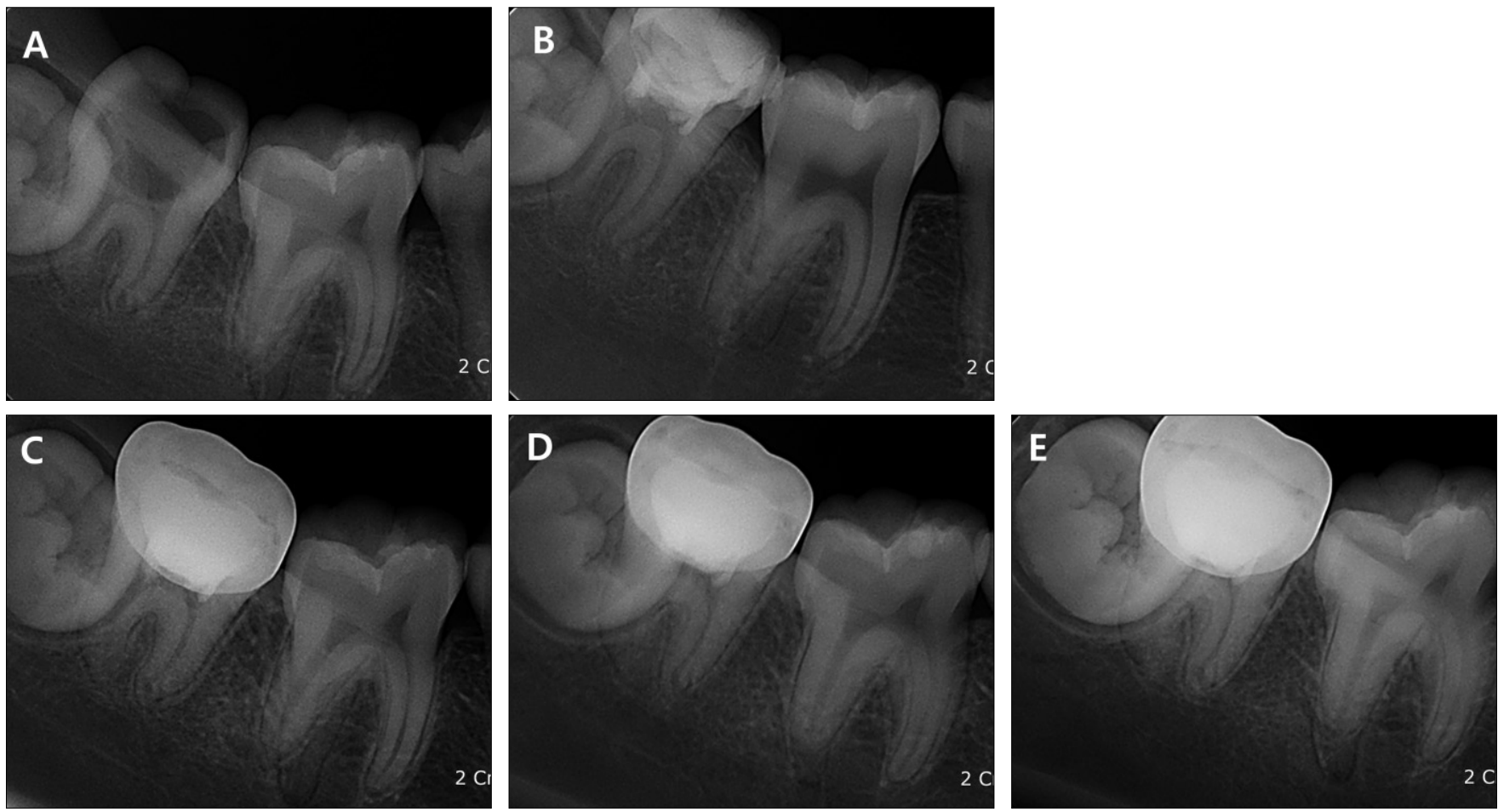

Fig. 4. Periapical view of the case 2. (A) Preoperative radiograph showing a deep caries of the right mandibular second molar. (B, C, D, E) Follow-up radiographs showing the periapical status at 1 month, 3 months, 7 months, and 11 months, respectively. Lengthening and thickening of roots with normal periodontal ligament space were observed. 
versible pulpitis. However, several clinical and histological studies have revealed that even irreversibly inflamed pulps maintain their healing potentia ${ }^{11.14)}$. In this study, one case was symptomatic, but the results showed that apexogenesis treatment can provide successful outcomes if the correct technique and appropriate biomaterials are used.

In recent years, MTA has been introduced for pulpotomy and has demonstrated good biocompatibility and $\mathrm{ex}^{-}$ cellent sealing ability ${ }^{15}$. However, a number of laboratory studies have evaluated the biocompatibility of MTA by measuring various parameters, such as proliferation and viability, using different types of cells in direct and/or indirect contact with MTA. MTA in its freshly mixed state shows high cytotoxicity ${ }^{7.8)}$, which could be due to its high $\mathrm{pH}^{9}$. Therefore, it is important to develop biocompatible treatments directed at maintaining pulp vitality and increasing tooth longevity ${ }^{10)}$. One such biologically based therapeutic is PRF. PRF is a second-generation platelet concentrate that is widely used to accelerate soft and hard tissue healing. PRF is a strictly autologous fibrin matrix containing a large quantity of platelet and leucocyte cytokines ${ }^{16}$. Growth factors play a pivotal role in signaling the events of tissue formation and repair in the dentine-pulp complex. They are responsible for signaling many of the key events in tooth morphogenesis and differentiation, and the recapitulation of these processes after dental injury allows for tissue regeneration ${ }^{17.18)}$. In the current cases, an effort was made to use these growth factors to support root development. Hiremath et al. ${ }^{19)}$ reported PRF as a medicament of a permanent molar with pulpitis in 2012. They restored the tooth with a crown after pulpotomy. Clinical symptoms, such as pain, were assessed, and radiographs were analyzed during 22 months of follow-up. They concluded that pulpotomy with PRF could be an alternative treatment to MTA or other materials in mature permanent teeth with pulpitis.

As discussed earlier, PRF was prepared with the $\mathrm{pa}^{-}$ tient's blood and placed in the pulp chamber after a pulpotomy procedure. The PRF accounts for a favourable physiologic structure to support root development. A layer of MTA was placed over the PRF, and glass-ionomer cement was added. MTA was chosen because it is hydrophilic and requires moisture to set, which is a favorable property when there is the potential for moisture contamination in the clinical setting ${ }^{21}$. Also, MTA was used in order to maintain the healing of pulp tissues be- cause it has an ability to provide good sealing.

We obtained favorable clinical and radiographic outcomes in pulpotomy with PRF in symptomatic and asymptomatic cases. Pulpotomy with PRF could be an alternative treatment to other materials in immature permanent teeth with carious pulp exposure. Further research on this topic is required with regard to histological assessment with a larger sample size.

\section{Summary}

Pulpotomy using PRF could be a more biocompatible treatment due to its direct contact with vital pulp tissue. Although it has a disadvantage requiring blood sampling, growth factors in PRF can help to promote root development. Based on the short-term results of this study, pulpotomy with PRF could be an alternative treatment in immature permanent teeth with carious pulp exposure. Additionally, clinical observation over the long-term is necessary in the future.

\section{References}

1. Witherspoon DE, Small JC, Harris GZ : Mineral trioxide aggregate pulpotomies: a case series outcomes assessment. J Am Dent Assoc, 137: 610-618, 2006.

2. Holland G, Trowbridge H, Rafter M : Endodontics: principles and practice, 4th ed. Saunders Elsevier, ST Louis, 21-38, 2008.

3. Bakland LK : Endodontics, BC Decker Inc, Toronto, 795-844, 2002.

4. Stanley H : Criteria for standardizing and increasing credibility of pulp capping studies. Am J Dent, 11:17-34, 1998.

5. Holland R, de Souza V, de Otoboni Filho J, et al. : Permeability of the hard tissue bridge formed after pulpotomy with calcium hydroxide: a histologic study. J Am Dent Assoc, 99:472-475, 1979.

6. Torabinejad M, Parirokh M : Mineral trioxide aggregate: a comprehensive literature review-Part II: leakage and biocompatibility investigations. $J$ Endod, 36:190-202, 2010.

7. Haglund R, He J, Jarvis J, Zhu Q, et al. : Effects of root-end filling materials on fibroblasts and macrophages in vitro. Oral Surg Oral Med Oral Pathol Oral Radiol Endod, 95:739-745, 2003.

8. Balto HA : Attachment and morphological behavior of human periodontal ligament fibroblasts to mineral 
trioxide aggregate: a scanning electron microscope study. J Endod, 30:25-29, 2004.

9. Camilleri $J$ : Characterization of hydration of mineral trioxide aggregate. Int Endod $J, 41: 408-417$, 2008.

10. Wang Z, Pan J, Preisser JS, et al. : Putative stem cells in human dental pulp with irreversible pulpitis: an exploratory study. J Endod, 36:820-825, 2010.

11. Witherspoon DE : Vital pulp therapy with new materials: new directions and treatment perspectives-permanent teet. J Endod, 34:25-28, 2008.

12. Choukroun J, Diss A, Dohan DM, et al. : Plateletrich fibrin $(\mathrm{PRF})$ : a second-generation platelet concentrate. Part IV: clinical effects on tissue healing. Oral Surg Oral Med Oral Pathol Oral Radiol Endod, 101:299-303, 2006.

13. Massler M : Therapy conductive to healing of the human pulp. Oral Surg Oral Med Oral Pathol, 34:122-130, 1972.

14. Eghbal M, Asgary S, Ghoddusi J, et al. : MTA pulpotomy of human permanent molars with irreversible pulpitis. Aust Endod J, 35:4-8, 2009.

15. Asgary S, Eghbal MJ, Rahimi H, et al. : A comparative study of histologic response to different pulp capping materials and a novel endodontic cement.
Oral Surg Oral Med Oral Pathol Oral Radiol Endod, 106:609-614, 2008.

16. Sunitha Raja V, Munirathnam Naidu E : Plateletrich fibrin: evolution of a second-generation platelet concentrate. Indian J Dent Res, 19:42-46, 2008.

17. Smith AJ : Vitality of the dentin-pulp complex in health and disease: growth factors as key mediators. $J$ Dent Educ, 67:678-689, 2003

18. Kim HN, Lee NY, Lee SH : Regenerative endodonctic treatment of immature permanent teeth by using platelet-rich fibrin. J Korean Acad Pediatr Dent, 39:174-180, 2012

19. Hiremath H, Saikalyan S, Hiremath V, et al. : Second-generation platelet concentrate $(\mathrm{PRF})$ as a pulpotomy medicament in a permanent molar with pulpitis: a case report. Int Endod J, 45:105-112, 2012.

20. Waterhouse P, Whitworth J, Camp J, Fuks A : Pathways of the Pulp, 10th ed. Mosby, St. Louis, 808-857, 2011.

21. Yoon YM, Lee NY, Lee HS : Conservative endodontic treatment of permanent teeth with periapical lesions: case reports. J Korean Acad Pediatr Dent, 38:276-283, 2011. 
국문초록

미성숙 영구치에서 혈소판 농축 섬유소를 적용한 생활 치수 치료 : 증례보고

이가영 · 이상호 · 이난영

조선대학교 치의학전문대학원 소아치과학교실

심한 우식을 보이는 미성숙 영구치 치료에 있어서 치수생활력을 보존하는 것은 중요하다. 치수절단술을 시행 시 생체적합 성이 있는 재료를 이용하여 치료함으로써 남아있는 생활력이 있는 치수를 보호하며 미성숙 영구치의 치근 성장을 도모할 수 있다. 혈소판 농축 섬유소는 환자의 혈액을 직접 채취하여 적용하기 때문에 생체적합성이 뛰어나며 다양한 성장인자를 함유 하고 있어 치수생활력을 유지하고 미성숙 영구치의 치근 발육을 촉진시킬 수 있다.

본 증례에서는 심한 치아 우식증을 보이는 미성숙 영구치에서 치수절단술 시행 후 남아 있는 치수 상부에 혈소판 농축 섬 유소를 적용하였다. 정기적인 검진 결과 미성숙 영구치의 치근 성장 및 정상적인 치아 주위 조직들이 관찰되었다. 향후 장기 간의 임상적 관찰이 필요할 것이며 더 많은 임상 증례를 바탕으로 한 연구가 필요할 것이다.

주요어: 치수절단술, 혈소판 농축 섬유소, 미성숙 영구치 